Abstracta Iranica Abstracta Iranica

Revue bibliographique pour le domaine irano-aryen

Volume 30 | 2010

Comptes rendus des publications de 2007

\title{
Persian Responses. Political and Cultural Interaction with(in) the Achaemenid Empire. Swansea, The Classical Press of Wales, 2007, XXV-373 p., ill., index.
}

\section{Rémy Boucharlat}

\section{(2) OpenEdition}

\section{Journals}

Édition électronique

URL : http://journals.openedition.org/abstractairanica/37696

DOI : 10.4000/abstractairanica.37696

ISSN : 1961-960X

Éditeur :

CNRS (UMR 7528 Mondes iraniens et indiens), Éditions de l'IFRI

Édition imprimée

Date de publication : 8 avril 2010

ISSN : 0240-8910

\section{Référence électronique}

Rémy Boucharlat, «Persian Responses. Political and Cultural Interaction with(in) the Achaemenid Empire.

Swansea, The Classical Press of Wales, 2007, XXV-373 p., ill., index. », Abstracta Iranica [En ligne],

Volume 30 | 2010, document 96, mis en ligne le 08 avril 2010, consulté le 26 septembre 2020. URL

http://journals.openedition.org/abstractairanica/37696; DOI : https://doi.org/10.4000/

abstractairanica.37696

Ce document a été généré automatiquement le 26 septembre 2020.

Tous droits réservés 


\title{
Persian Responses. Political and Cultural Interaction with(in) the Achaemenid Empire. Swansea, The Classical Press of Wales, 2007, XXV-373 p., ill., index.
}

\author{
Rémy Boucharlat
}

1 Ce volume dérive d'une réunion tenue à l'université de Rennes II en 2004. Certaines communications ne sont pas reprises dans ce volume tandis que des articles ont été sollicités après la réunion. La diversité des interventions est regroupée dans l'introduction de l'éditeur sous quelques rubriques, dans un ordre un peu différent de celui de la présentation du livre: «Greek historiography» (N. Sekunda, G. Danzig J. Hyland) ; «Persian display » (D. Lenfant, C. Tuplin) ; «Regional studies» (deux sur l'Anatolie, F. Maffre et E. Raimond ; une sur l'Egypte, A. Lloyd, et une sur la Babylonie, W. Henkelman K. Kleber). "The limits of cultural response " (M Root, P. Vasunia); «Post-antique reception» (St John Simpson et L. Allen sur Persépolis), « Alexander's Persian Empire » (R. Lane Fox). Ces thèmes sont une juxtaposition plus qu'un ensemble, mais cette réunion était en réalité une occasion de maintenir le contact entre spécialistes qui n'ont plus les Achaemenid Workshops (voir la série des Achaemenid History I-VIII, 1987-1994) pour se rencontrer. L'éditeur affirme qu'il y a encore place pour de tels colloques ouverts, car les autres réunions sont devenus très thématiques (archéologie, numismatique, un auteur ancien) ou régionales. Sans doute, cette diversité est stimulante, en particulier au cours du colloque lui-même, mais les articles publiés dans une série généraliste courent le risque de passer un peu inaperçus, plus qu'ils ne le seraient s'ils étaient donnés chacun dans diverses revues que les lecteurs suivent régulièrement. On touche à la question récurrente de la place des études achéménides dans l'histoire de l'Antiquité : un objet limité dans le temps, deux siècles, mais recouvrant des mondes très différents qu'abordent des spécialistes issus 
d'horizons distincts, même si la plupart des intervenants à ce colloque étaient de toute évidence des historiens de formation classique.

INDEX

Thèmes : 3.2.2. Pré-Achéménides et Achéménides

\section{AUTEURS}

RÉMY BOUCHARLAT

CNRS - Lyon 